\title{
HUBUNGAN PENGETAHUAN LANSIA TENTANG PELAKSANAAN SENAM LANSIA DI PANTI JOMPO KHUSNUL KHATIMAH KEC. MARPOYAN DAMAI PEKANBARU TAHUN 2019
}

\author{
Juli Selvi Yanti, Eka Maya Saputri, Marren Prayang \\ STIKes Hang Tuah Pekanbaru \\ Email: juliselviyanti.jsy@htp.ac.id
}

\begin{abstract}
ABSTRAK
Gymnastics for the elderly is a light and easy exercise, not burdensome that can be applied to the elderly. This sports activity will help the body to stay fit and stay fresh because elderly exercise is able to train bones to stay strong, encourage the heart to work optimally and help eliminate free radicals that roam the body. At the Khusnul Khatimah Nursing Home, Pekanbaru. This type of research is quantitative analysis which was conducted on 02 November - 27 April 2016 at the Khusnul Khatimah Nursing Home, Pekanbaru. And with a cross sectional approach, with a total sample of 67 respondents of which 10 respondents could not be communicated with. This study used a questionnaire containing questions related to the Knowledge Relationship of the Elderly with the Implementation of Elderly Gymnastics at the Khusnul Khatimah Nursing Home in 2016. Meanwhile, 12 (46.2\%) elderly with less knowledge about the elderly exercise (46.2\%), while $32(78 \%)$ respondents with good knowledge of the elderly exercise. Hypothesis testing used the Chi-Square test at alpha $=0.05$ with $p$ value $=0.008$ so that it was concluded that there was a relationship between knowledge of the elderly and the implementation of elderly exercise at the Khusnul Khatimah Nursing Home in 2016

Keywords: Knowledge, Elderly Gymnastics Implementation
\end{abstract}

\section{ABSTRAK}

Senam lansia adalah olahraga ringan dan mudah dilakukan, tidak memberatkan yang dapat diterapkan pada lansia. Aktifitas olahraga ini akan membantu tubuh agar tetap bugar dan tetap segar karena senam lansia ini mampu melatih tulang tetap kuat, mendorong jantung bekerja secara optimal dan membantu menghilangkan radikal bebas yang berkeliaran di dalam tubuh. Di Panti Jompo Khusnul Khatimah Pekanbaru.

Jenis penelitian ini adalah Analitik Kuantitatif yang dilakukan pada tanggal 02 November - 27 April 2016 di Panti Jompo Khusnul Khatimah Pekanbaru. Dan dengan pendekatan cross sectional.dengan jumlah sampel sebanyak 67 responden yang mana 10 orang responden yang tidak bisa di ajak berkomunikasi Penelitian ini menggunakan kuesioner yang berisikan tentang pertanyaan yang berkaitan dengan Hubungan Pengetahuan Lansia dengan Pelaksanaan Senam Lansia di Panti Jompo Khusnul Khatimah Pekanbaru tahun 2016.

Sedangkan lansia dengan berpengetahuan kurang dengan pelaksanaan senam lansia sebanyak $12(46,2 \%)$, sedangkan lansia berpengetahuan baik dengan pelaksanaan senam lansia sebanyak $32(78 \%)$ responden. Uji hipotesis menggunakan uji Chi-Square pada alpha $=0,05$ dengan nilai $\mathrm{p}=0,008$ sehingga disimpulkan terdapat hubungan antara pengetahuan lansia dengan pelaksanaan senam lansia di Panti Jompo Khusnul Khatimah Pekanbaru tahun 2016

\section{Kata Kunci : Pengetahuan, Pelaksanaan Senam Lansia}




\section{PENDAHULUAN}

Lansia (55-65 tahun) merupakan suatu bagian dari tahap perjalanan hidup manusia yang keberadaannya senantiasa harus diperhatikan. Pandangan sebagian masyarakat yang menganggap lansia sebagai manusia yang tidak mampu, lemah, dan sakit-sakitan menyebabkan mereka memperlakukan lansia sebagai manusia yang tidak berdaya, sehingga segala aktivitasnya sangat dibatasi (Menuh, 2007).

Pada usia 55-65 tahun merupakan kelompok umur yang mencapai tahap pensiun, pada tahap ini akan mengalami berbagai penurunan daya tahan tubuh atau kesehatan dan berbagai tekanan psikologis.Dengan demikian akan timbul perubahan-perubahan dalam hidupnya (Saparinah 1983).

Senam Lansia adalah olahraga ringan dan mudah dilakukan,tidak memberatkan yang diterapkan pada lansia. Senam lansia merupakan olahraga yang cocok bagi lansia karena gerakan didalamnya menghindari gerakanloncatloncat (low impact),melompat, kaki menyilang,maju mundur,menyentaksentak namun masih dapat memacu kerja jantung-paru dengan intensitas ringansedang,bersifat menyeluruh dengan gerakan yang melibatkan sebagian beasar otot tubuh,serasi sesuai gerak sehariharidan mengandung gerakan- gerakanmelawan beban badan dengan pemberian beban antara kanan dan kiri tubuh secara seimbang dan berimbang.Gerakan dalam SBL mengandung gerakan-gerakan yang diharapakan dapat merningkatkan komponen kebugaran Kardiorespirasi,kekuatan dan ketahan otot,kelenturan dan komposisi badan yang seimbang (Suhardo,2004)

Pada lanjut usia terjadi penurunan masa otot serta kekuatannya,laju denyut jantung maksimal,toleransi latihan dan dan terjadinya peningkatan lemak tubuh.dengan melakukan olahraga seoperti senam lansia dapat mencegah atau melambatkan kehilangan fungsional tersebut.bahkan dari berbagai penelitian menunjukan bahwa latihan/olahraga seperti senam lansia dapat mengeliminasi berbagai resiko penyakit seperti hipertensi,diabetes militus,penyakit arteri koroner,dan kecelakaan (Darmojo 1999;81).

Jumlah lansia di Indonesia tahun 2006 berdasarkan hasil sensus sekitar 19 juta jiwa dengan AHH (Angka Harapan Hidup) 66,2 tahun. Pada tahun 2010 jumlah lansia sekitar 23,9 juta jiwa dengan AHH 67,4 tahun. Pada tahun 2020 diperkirakan jumlah lansia sekitar 28,8 juta jiwa dengan AHH 71,1 tahun.

Badan kesehatan dunia (WHO) Menetapkan 65 tahun sebagai usia yng 
menunjukan proses penuaan yang berlangsung secara nyata dan seseorang telah disebut lanjut usia. Lansia banyak menghadapi berbagai masalah kesehatan yang perlu penangan segera dan terintegrasi.

Jumlah lansia menurut Survey Demokrasi Kemerdekaan Indonesia (SDKI) pada tahun 2002 berjumlah sebanyak 15.30 juta jiwa,pada tahun 2007 berjumlah sebanyak 18.96 juta jiwa, dan meningkatnya jumlah lansai pada tahun 2012 yaitu berjumalah sebanyak 24.88 juta jiwa.

Menurut Undang-Undang No.13 tahun 1998 lansia adalah orang yang telah berusia 60 tahun keatas.Sebagai wujud dari penghargaan terhadap orang lanjut usia,pemerintah membentuk komnas lansia (Komisi Nasional Perliundungan Penduduk lanjut usia),dan merancang rencana aksi nasional lanjut usia dibawah koordinasi kantor Menko Kesra.Komnas landsia dibentuk berdasarkan KeppresNo 52 tahun 2004 dan bertugas sebagai coordinator usaha peningkatan kesejateraan social orang lanjut usia diindonesia.

Penduduk antar sensus (Supas) yang dialukan badan pusat statistic (BPS),lansia di propinsi riau pada tahun 2005 berjumlah sekitar 173.606 jiwa atau 3,8 persen dari jumlah penduduk 4.563.406.Pada tahun 2010 jumlah lansia di Riau bertambah menjadi 225.353 jiwa atau 4,1 persen dari total penduduk riau,5.538.367.dari j7umlah tersebut terdapat 80.602 jiwa lansia tinggal di perkotaan dan 144.751 jiwa lansia tinggal dipedesaan.dari kedua daerah tersebut lansia perempuan lebih banyak disbanding lansia laki-laki (Sensus Penduduk 2010).

Berdasarkan hasil penelitian Ardiyanti (2009),lansia yang mengikuti senam secara rutin dapat melakukan aktivitas dasar sehari-hari di dalam panti sebesar $96,23 \%$.

Berdasarkan hasil penelitian Spearman (2012) antara pengetahuan dengan keaktifan lansia diporoleh nilai 0,774 dan nilai $\mathrm{p}=0,000$. sehingga disimpulkan bahwa pengetahun lansia tentang posyandu lansia termasuk kategori kurang.

Berdasarkan hasil penelitian Dalyoko,Dyah Ayu Pithaloka (2010) bahwa ada hubungan antara sikap $(\mathrm{p}=0,000)$,pengawasan dan pihak keluarga $\quad(p=0,003)$,dan pengetahuan $(\mathrm{p}=0,016)$ dengan upaya pengendalian hipertensi di psyandu lansia Wilayah Kerja Puskesmas Mojosongo Boyolali.

Berdasarkan Survey awal yang dilakukan terhadap 10 orang Lansia yang ada di Panti Jompo Khusnul Khatimah Pekanbaru maka diperoleh tidak ada lansia yang memeliki pengetahuan 
Kurang tentang senam Lansia, 10 orang Lansia yang memiliki pengetahuan Baik tentang senam Lansia.

Berdasar dari latar belakang diatas saya teretarik untuk melakukan penelituian tentang "Hubungan pengetahuan Lansia dengan Pelaksanaan Senam Lansia" ini untuk mengetahui apakah ada hungannya pengetahuan lansia dengan pelaksanaan senam lansia tersebut

\section{METODE KEGIATAN}

Dalam melakukan penelitian ini penulis menggunakan jenis penelitian Analitik Kuantitatif yaitu untuk mengetahui Hubungan Pengetahuan Lansia dengan pelaksanaan senam Lansia,dengan menggunakan desain pendekatan study cross sectional dimana dalam sistem ini variabel-variabelnya diukur dalam waktu yang bersamaan (Notoatmodjo, 2010).

\section{HASIL DAN PEMBAHASAN}

\section{Hasil Penelitian}

Berdasarkan penyebaran kuesioner tentang pengetahuan lansia dengan penatalaksanaan senam lansia di Panti Jompo Khusnul Khatimah Pekanbaru Tahun 2019 dapat dilihat pada tabel berikut.

\section{Tabel 4}

Hubungan Pengetahuan Lansia dengan Pelaksanaan Senam Lansia Di Panti Jompo khusnul Khatimah Pekanbaru Tahun 2019

\begin{tabular}{|c|c|c|c|c|c|c|c|}
\hline \multirow{3}{*}{ No. } & \multirow{3}{*}{ pengetahuan } & \multicolumn{5}{|c|}{ Pelaksanaan Senam Lansia } & \multirow{3}{*}{$\begin{array}{c}\text { p. } \\
\text { Value }\end{array}$} \\
\hline & & \multicolumn{2}{|c|}{ Ya } & \multicolumn{2}{|c|}{ Tidak } & \multirow{2}{*}{ Total } & \\
\hline & & Jumlah & $\%$ & Jumlah & $\%$ & & \\
\hline 1. & Baik & 32 & $78 \%$ & 9 & $22 \%$ & 41 & \multirow{2}{*}{0,008} \\
\hline 2. & Kurang & 12 & $46,2 \%$ & 14 & $53,8 \%$ & 26 & \\
\hline & Jumlah & 44 & $65,7 \%$ & 23 & $34,3 \%$ & 67 & \\
\hline
\end{tabular}

Berdasarkan tabel di atas terdapat lansia dengan pengetahuan kurang dengan penatalaksanaan senam lansia sebanyak $12(46,2 \%)$ sedangkan lansia dengan pengetahuan baik dengan penatalaksanaan sebanyak 32 (78\%). Hasil uji statistik Chi-Square pada alpha $=0,05$ didapatkan nilai $\mathrm{p}=0,008$ berarti terdapat hubungan antara pengetahuan lansia dengan pelaksanaan senam lansia di Panti Jompo Khusnul Khatimah Pekanbaru Tahun 2019. 
Pembahasan

Menurut Notoadmodjo 2007) Pengetahuan adalah hasil "Tahu" dan ini terjadi setelah orang melakukan penginderaan terjadi melalui panca indera manusia yaitu indera penglihatan, pendengaran, peenciuman, rasa dan raba..Sebagian besar pengetahuan manusia diperoleh melalui mata dan telinga. Dari hasil penelitian dapat diketahui bahwa mayoritas responden berpengetahuan kurang mendapatkan informasi tentang penatalaksanaan senam lansia.

Penelitian ini sejalan dengan penelitian Paryanti (2011), tentang "Hubungan Antara Pengetahuan Lanjut Usia Tentang Senam dengan keaktifan dalam Mengikuti Senam di Posyandu Desa Ngargorejo Ngemplak Bayolali” dengan $p \quad$ value $=0,001, \quad$ sehingga disimpulkan terdapat hubungan antara pengetahuan lansia tentang senam dengan keaktifan dalam mengikuti kegiatan senam di posyandu desa ngargorejo ngemplak boyolali.

Penelitian ini sejalan dengan penelitian Widyantoro Putra (2012), tentang "Hubungan Anatara Senam Lansia dan Range of Mation (ROM) Lutut Pada Lansia" dengan $p$ value $=0,001$, sehingga disimpulkan senam lansia berhubungan terhadap Range Of Mation (ROM) lutut lansia.
Menurut asumsi peneliti, kurangnya pengetahuan lansia tentang penatalaksanaan senam lansia diatas dapat disebabkan oleh faktor kurangnya informasi yang diperoleh atau dapat disebabkan karena faktor lupa atas informasi yang pernah mereka terima baik dari pihak Puskesmas ataupun dari berbagai sumber informasi lainnya. Ini terkait dengan usia para lansia yang tidak mampu lagi untuk banyak mengingat informasi yang mereka terima. Semakin uzur usia seseorang maka semakin menurun daya ingat dan daya konsentrasi seseorang tersebut.

\section{KESIMPULAN}

Dari 67 orang responden yang diteliti didapatkan hasil bahwa sebagian besar pengetahuan kurang dengan pelaksanaan senam lansia sebanyak 12 $(46,2 \%)$ sedangkan lansia dengan pengetahuan baik dengan pelaksanaan senam lansia sebanyak 32 (78\%). Hasil uji statistic Chi-Square pada alpha $=0,05$ didapat nilai $\mathrm{p}=0,008$ terdapat ada hubungan antara pengetahuan lansia dengan pelaksanaan senam lansia di Panti Jompo Khusnul Khatima pekanbaru 2019. 
DAFTAR PUSTAKA

Bandiyah, Siti. 2009. Lanjut Usia dan Keperawatan

Gerontik.

Yogyakarta: Nuha Medika.

Direktorat Bina Gizi Masyarakat Depkes

RI, 2008. Petunjuk Menyusun Menu Bagi Usia

Lanjut.Departemen Kesehatan, Jakarta

Hartono, Andry. 2008. Gizi Bagi Manula,Kompas, 18 Agustus.

Kartari DS, 2009. Manusia usia lanjut. Disampaikan dalam Diskusi Ilmiah Badan Litbangkes Depkes RI, Jakarta, 30 Januari.

Kusmana, Dede. 2011. Olahraga pada usia Lanjut. Simposium menuju hidup sehat pada usia lanjut. Bogor, 7 November.

Nugroho, Wahjudi, Keperwatan Gerontik. Jakarta: EGC

Soekidjo, $\quad$ Notoadmodjo. 2010. Metodologi Penelitian Kesehatan. Jakarta: PT Rineka Cipta.

Https: // Yuliakusumadewi. Wordpress.com/2012/03/12/Peng ertian lansia
Machfoedz, I. 2010. Metode Penelitian Kuantatif \& Kualitatif Bidang Kesehatan

Keperawatan, Kebidanan,

Kedokteran. Yogyakarta:

Fitramaya.

Kushariyadi. 2010. Asuhan Keperawatan Pada Klien Lanjut Usia. Jakarta: Salemba Medika.

Tri Widianti, A \& Proverawati, A. 2010. Senam kesehatan. Yogyakarta: Nuha Medika.

Widfyantoro, Putra. 2012. Hubungan antara Senam lansia dan Range Of Mation (ROM) Lutut Pada Lansia, Fakultas Kedokteran Universitas Islam Sultan Agung: Semarang

Paryanti, yani. 2011. Hubungan Antara Pengetahuan Lanjut Usia Tentang Senam dengan Keaktifan Dalam Mengikuti Senam, Fakultas Ilmu Kesehatan Unuversitas

Muhammadiyah: Sukarta 